\title{
Histological Organization of Thyroid and Interrenal Glands of the Pearl Mullet, Alburnus tarichi (Cypriniformes: Cyprinidae) from Lake Van Basin of Turkey \\ (Pengaturan Histologi Kelenjar Tiroid dan antara Renal Ikan Belanak Mutiara, Alburnus tarichi (Cypriniformes: Cyprinidae) dari lembangan Tasik Van, Turki)
}

\author{
BURAK KAPTANER*
}

\begin{abstract}
In this study, histological organizations of the thyroid and interrenal glands were first investigated in pearl mullet (Alburnus tarichi Güldenstädt, 1814), living in the Lake Van basin in Turkey. The serial sections taken from the subpharyngeal region and kidney were stained with hematoxylin and eosin, Mallory's trichrome and periodic acid-Schiff/hematoxylin and then examined. The histological examinations showed that the thyroid gland of pearl mullet was unencapsulated and the thyroid follicles were scattered diffusely in the subpharyngeal region, located at the dorsal and lateral aspects of the ventral aorta. The follicles had colloid-filled lumens and were surrounded by simple follicular epithelial cells varying in shapes (squamose, cuboidal and cylindrical). Thyroid follicles were not found in any areas of the kidney. The interrenal and chromaffin tissue were observed to be associated with postcardinal vein with its branches in the head of the kidney. The interrenal cells having a deeply eosinophilic cytoplasm were determined adjacent to branches in the head kidney. The eosinophobic chromaffin cells were found to show two different distributions. They were observed as being intermingled with the interrenal cells and formed separate groups surrounded by a thin connective tissue in the walls of the major veins. Both interrenal and chromaffin cells displayed a negative periodic acid-Schiff reaction.
\end{abstract}

Keywords: Alburnus tarichi; histology; interrenal gland; thyroid gland

\section{ABSTRAK}

Dalam kajian ini, pengaturan histologi kelenjar tiroid dan antara renal dikaji kali pertama dalam ikan belanak mutiara (Alburnus tarichi Güldenstädt, 1814) yang hidup di lembangan Tasik Van di Turki. Bahagian keratan yang diambil dari rantau subfarinks dan buah pinggang telah diwarna dengan hematoksilin dan eosin, trikrom Mallory dan asid berkalaSchiff/hematoksilin dan seterusnya dikaji. Pemeriksaan histologi menunjukkan bahawa kelenjar tiroid daripada ikan belanak mutiara telah dikapsul dan folikel tiroid tersebar resap di rantau subfarinks, terletak pada aspek dorsal dan sisian aorta ventral. Folikel mempunyai lümen koloid yang dipenuhi dan dikelilingi oleh pelbagai bentuk (squamose, cuboidal dan silinder). Folikel tiroid tidak ditemui dalam mana-mana bahagian buah pinggang. Tisu dalaman dan kromafin diperhatikan dikaitkan dengan urat pasca kardinal dengan cawangannya di kepala buah pinggang. Sel-sel antara renal yang mempunyai sitoplasma yang sangat eosinofilik, ditentukan berdekatan dengan cabang-cabang dalam kepala buah pinggang. Sel eosinofobik kromafin dilihat menunjukkan dua taburan berbeza. Mereka diperhatikan bercampur dengan sel antara renal dan membentuk kumpulan berasingan yang dikelilingi oleh tisu sambungan nipis di dalam dinding saluran vena utama. Kedua-dua sel antara renal dan kromafin menunjukkan tindak balas asid berkala-Schiff yang negatif.

Kata kunci: Alburnus tarichi; histologi; kelenjar antara renal; kelenjar tiroid

\section{INTRODUCTION}

The thyroid gland is responsible for the production and secretion of thyroid hormones, namely triiodothyronine and tetraiodothyronine or thyroxine. The functional units for biosynthesis of the thyroid hormones in the thyroid gland are thyroid follicles composed of thyrocytes enclosing a thyroglobulin-containing colloid matrix. The hormones are synthesized under the control of a thyroid stimulating hormone (TSH) from the pituitary gland (Eales \& Brown 1993). Thyroid hormones play an important role in the control of physiological events, such as metamorphosis, growth, metabolism, reproduction and osmoregulation in fish (Leatherland 1994). Tetrapods possess discrete, highly vascularized, glands that are paired (mammals, birds and amphibians) or present as a single midline tissue mass (most reptiles). Similarly, cartilaginous fishes have a single thyroid gland located in the midline of the lower jaw. In all cases, the thyroid is surrounded by a capsule of connective tissue, although some species (urodele amphibians) commonly have 'accessory' thyroid follicles in other places. Unlike the above mentioned vertebrates, in most teleostean fish, the thyroid is unencapsulated and isolated thyroid follicles are scattered throughout the connective tissue of the lower jaw in the vicinity of the ventral aorta (Leatherland 1994; Raine 2011). The teleostean thyroid is highly variable between and within taxa in terms of its form 
and location. The thyroid follicles can be found in ectopic sites located outside of the typical subpharyngeal region. The most common site for the ectopic or heterotropic thyroid is head kidney, although other nonpharyngeal regions (eye, spleen and brain) have been identified in fish, usually afflicted by goiters (Leatherland 1994). Heterotropic thyroid follicles have also been described in members of the family Cyprinidae, including common carp (Cyprinus carpio) and goldfish (Carrasius auratus) (Geven et al. 2007).

In teleosts, a separate adrenal gland, having cortex and medulla layers, does not present, as in the higher vertebrates. It has been suggested that the steroid-producing interrenal gland in fish is homologous to the adrenal cortex, whereas the catecholamine-producing chromaffin cells are homologous to the mammalian medullary cells. Both cell types are usually distributed in the anterior (head) kidney and surround the postcardinal vein and its branches (Gallo $\&$ Civinini 2003). The release of corticosteroids (cortisol) upon stimulation of the brain-pituitary-interrenal axis and release of catecholamines (adrenaline and noradrenaline) upon stimulation of the brain-sympathetic-chromaffin cell axis together constitute what is referred to as the stress in fish (Janz 2000). It has been reported that the intermingling position and distribution of the interrenal and chromaffin cells associated with the postcardinal vein and its branches can vary depending on the fish species (Abdel-Aziz 2010; Chakrabarti \& Ghosh 2014; Rocha et al. 2001).

Pearl mullet (Alburnus tarichi Güldenstädt, 1814) is a Cyprinid species endemic to the Lake Van basin of Turkey. It is anadromous, migrating to freshwater inlets for spawning during the reproduction phase (from mid-April to mid-June) (Danulat \& Selcuk 1992; Kaptaner \& Kankaya 2013). About 11,000 tons of these fish are caught annually, indicating that it is also economically important in the region. Up-to-date information regarding the description of the thyroid and interrenal glands in pearl mullet has not been reported. In the present study, we aimed to understand the histological organization of the thyroid and interrenal glands in this endemic species. Those results are reported here for the first time, and will provide basic knowledge for endocrinological studies in future for this fish species.

\section{MATERIALS AND METHODS}

The study was conducted on 6 sexually mature female pearl mullet (Alburnus tarichi Güldenstädt, 1814) (fork length: 20-22 cm and total weight: 90-120 g). The professional fishermen who caught the fish from the Lake Van basin $\left(43^{\circ} 13^{\prime} \mathrm{E}, 38^{\circ} 26^{\prime} \mathrm{N}\right)$ during the fishing season (from mid March to mid April) provided the study material. Ethical regulations were followed in accordance with national and institutional guidelines for the protection of animal welfare during the study. The fish used in this study died under natural circumstances. According to the Turkish Ministry of Forestry and Water Affairs regulations, the post mortem use of animal tissues does not require approval of the Animal Experiments Local Ethics Committee (The Official
Gazette of Republic of Turkey on February 15, 2014, No: 28914). An acceptance decision was also provided for this study by the Animal Experiments Local Ethics Committee of Van Yüzüncü Yil University. Immediately after the animals' death, the subpharyngeal region and kidney were carefully excised using fine scissors, scalpels and forceps. The tissues were fixed in Bouin's solution for $24 \mathrm{~h}$. The tissues were then dehydrated through a graduated ethanol series and embedded in paraffin. The cross-sections $(7 \mu \mathrm{m})$ from the subpharyngeal region and the longitudinal-sections from the kidney were taken and placed on adhesive silane-coated slides (Marienfeld $\mathrm{GmbH}$, Lauda-Königshofen, Germany). Next, the serial sections were deparaffinized in xylene and after rehydration with graded ethanol concentrations, they were stained with hematoxylin and eosin (H\&E), Mallory's trichrome (MT) and periodic acid-Schiff and hematoxylin (PAS\&H). All of the preparations were mounted with Canada balsam and examined under a Leica DMI 6000 B model microscope and photographed.

\section{RESULTS AND DISCUSSION}

The histological examinations showed that the thyroid tissue to be unencapsulated was scattered diffusely under the pharyngeal region, located at the dorsal and lateral aspects of the ventral aorta. The follicles were observed to be surrounded by adipose tissue from the upper side (Figure 1). Serial sections showed that the thyroid follicles were observed among the ventral aorta and afferent branchial arteries towards the posterior of the subpharyngeal region (Figure 1(A) - 1(C). The follicles had colloid-filled lumens and were surrounded by simple squamous, cuboidal and cylindrical follicular epithelial cells. A rounded nucleus situated near the basal membrane was found in the follicular epithelial cells (Figure 1(B) \& 1(D)). The follicles were surrounded by loose connective tissue (arrowheads) in contact with capillaries (Figure 1(B) \& 1(D)). Moreover, the histochemical studies on the colloid content indicated that it positively reacted with MT and PAS (Figure 1(D) - 1(F)), demonstrating the presence of rich glycoprotein. Unstimulated thyroid follicles were observed to have a squamous epithelial cell layer and large lumens whereas stimulated follicles displayed a cylindrical follicular epithelial cell layer (Figure 2).

The kidney of pearl mullet could roughly be divided into three parts; the head, trunk, and tail (Figure 3(A)). The head is the anterior portion of the kidney and is composed of bilateral lobes located ventrolateral to the spinal column. The head of the kidney in pearl mullet consists of lymphoid and hematopoietic tissues, melanomacrophage centers, the interrenal gland, chromaffin tissue, malpighian bodies and nephrons tubules (Figure 3(B)). The thyroid follicles were not observed in the head or other parts of the kidney. In pearl mullet, none of the thyroid follicles could be detected in the subpharyngeal region, located next to the ventral aorta in the gill arches. 


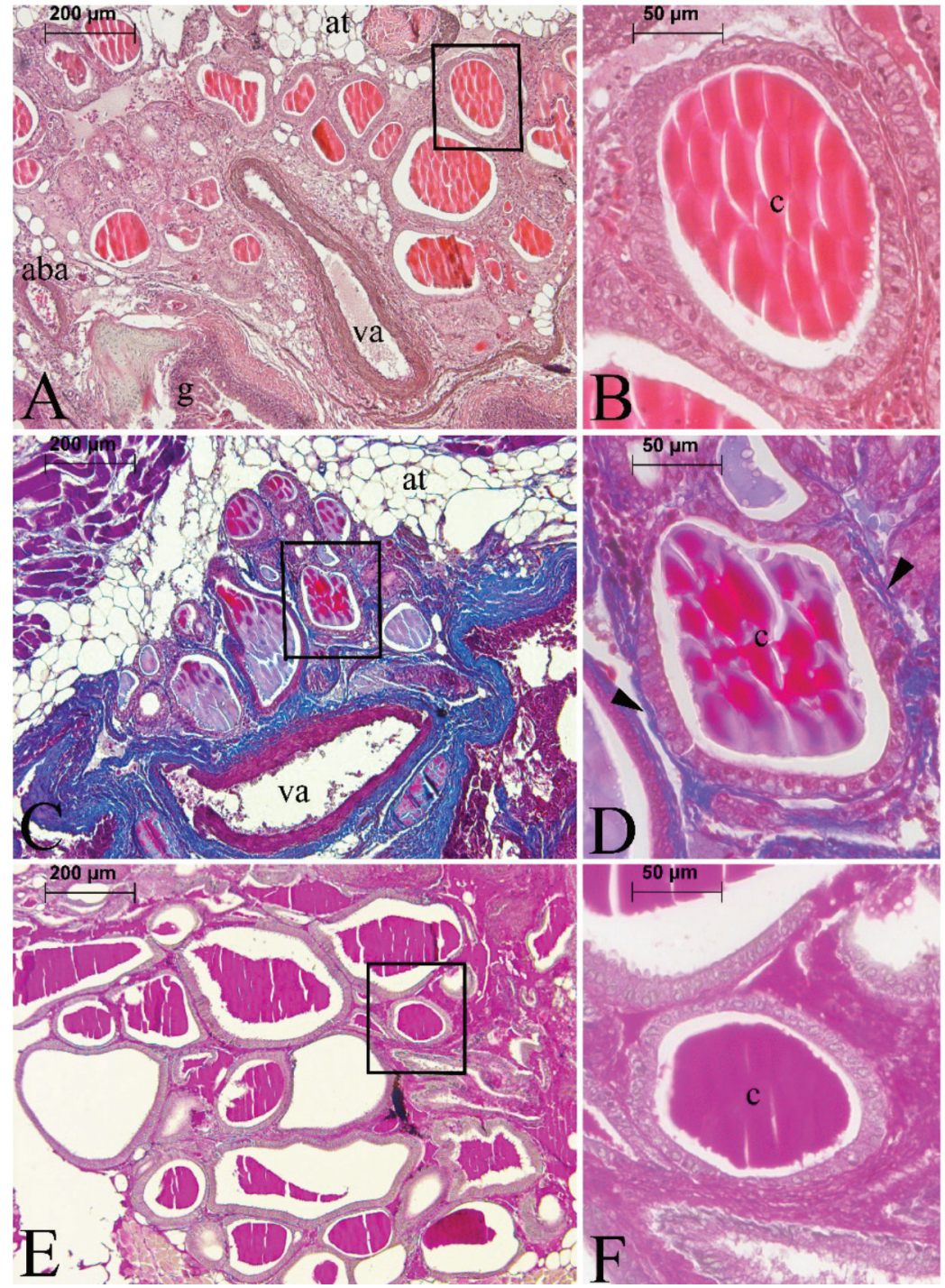

FIGURE 1. Cross-sections of pearl mullet subpharyngeal region stained with $\mathrm{H} \& \mathrm{E}$ (A, B), MT (C, D) and PAS\&H $(\mathrm{E}, \mathrm{F})$. The thyroid tissue was observed to be unencapsulated and scattered diffusely under the pharyngeal region, located at the dorsal and lateral aspects of the ventral aorta (va) (A, C). In the higher magnification of the thyroid follicles in the right panel, the follicles having simple cuboidal and cylindrical epithelial cells $(\mathrm{B}, \mathrm{D}, \mathrm{F})$ and surrounding by a thin connective tissue (D; arrowheads) can be seen and the colloid (c) filling the follicle lumen positively reacted by MT (C, D) and PAS (E, F). The colloid (c) was stained in a purple color with PAS staining (E, F), (aba: afferent branchial artery; at: adipose tissue; g: gill)

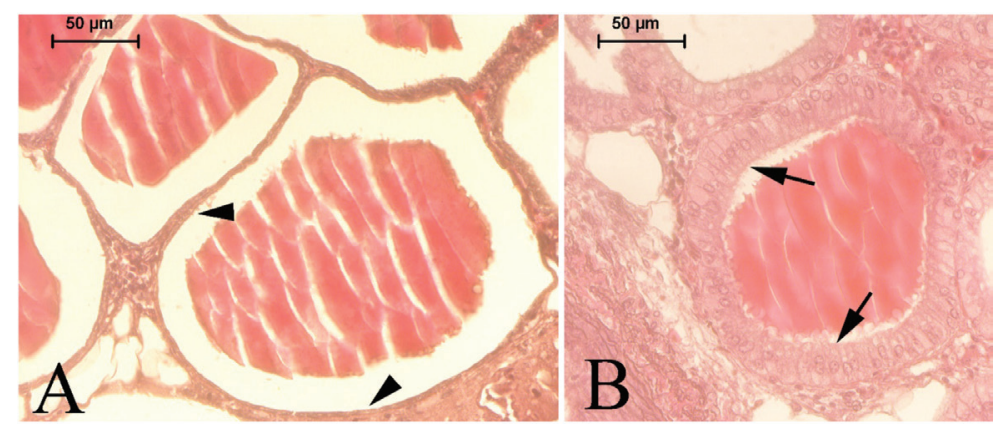

FIGURE 2. Representative photographs displaying unstimulated thyroid follicles (A) with squamous follicular epithelial cell layer (arrowheads) and stimulated follicles (B) with cylindrical epithelial cells (arrows) (H\&E) 


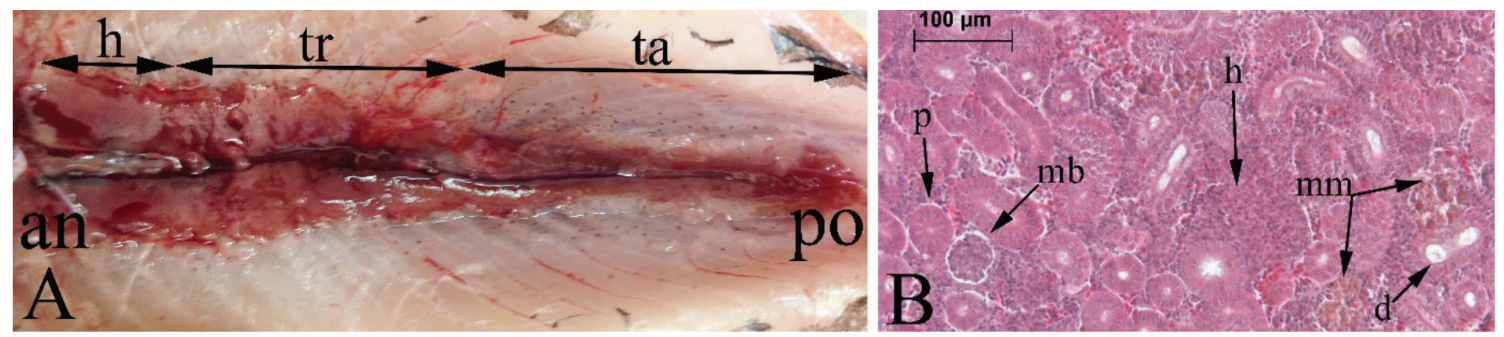

FIGURE 3. Photograph of the kidney of pearl mullet (A). The kidney could roughly be divided into three parts: a head (h), trunk (tr) and tail (ta) (an: anterior; po: posterior). In a longitudinal section from the head kidney (H\&E) and (B), hematopoietic tissue (h), melanomacrophage centers $(\mathrm{mm})$, malpighian body $(\mathrm{mb})$ and nephron segments, such as the proximal convoluted tubule (p) and distal convoluted tubule (d), can be seen (H\&E)

In pearl mullet, the interrenal and chromaffin tissues are detected in the right and left lobes of the head kidney closely associated with postcardinal vein and its branches. The interrenal gland cells were observed adjacent to major branches of the postcardinal vein. They formed one, two, three layers of cells, lining the blood vessel and were also determined to form masses. The interrenal gland cells were intermingled with chromaffin cells and were observed to enclose chromaffin cells lying adjacent to blood vessel. The chromaffin cells were located next to the vein wall and detectable singly and in clusters among the interrenal cells (Figure 4). Aside from the intermingled distribution of the chromaffin cells with the interrenal cells, they were also situated in groups in the walls of the main veins (Figure 5).

The interrenal cells were observed to be rounded, elongated and polygonal in shapes and smaller than the chromaffin cells. The cytoplasm of the interrenal cells was eosinophilic when stained with H\&E and acidophilic with MT (Figure 4(A), 4(B)). The nuclei of the interrenal cells were usually round and basophilic and had a conspicuous nucleolus. The chromaffin cells were larger than the interrenal cells and were mostly rounded and polygonal. When stained with H\&E and MT, they exhibited a pale cytoplasm. The large nucleus was slightly basophilic and had a prominent nucleolus (Figure 5(A) \& 5(B)). The chromaffin cells were also arranged in groups along the walls of the main veins and those groups were surrounded by a thin connective tissue (Figure 5(C)). A ganglion cell in the chromaffin cell group was also observed in some cases (Figure 5(D)). Neither the interrenal cells nor the chromaffin cells showed a positive PAS staining (Figure 6).

In pearl mullet, thyroid tissue was found to be located in the subpharyngeal region, in the vicinity of the ventral aorta and it did not evolve into a compact organ. The thyroid gland was observed to be unencapsulated and the scattered thyroid follicles were located along the lateral and upper sides of the ventral aorta. These observations are similar to those found in most other teleosts. In tilapia, Orechromis niloticus, thyroid follicles were reported to be found only in the subpharyngeal region (Geven et al. 2007). The thyroid tissue of medeka (Oryzias latipes) comprises two nuclei in the follicles, situated on either side of the ventral aorta (Raine et al. 2001). In rainbow trout, the clusters of follicles in the pharyngeal thyroid tissue present adjacent to the ventral aorta (Leatherland 1994; Raine \& Leatherland 2000). The thyroid is not a compact gland and it consists of scattered follicles that surround the ventral aorta and branchial arteries in short mackerel (Rastrelliger brachysoma) (Senarat et al. 2016). Heterotropic thyroid

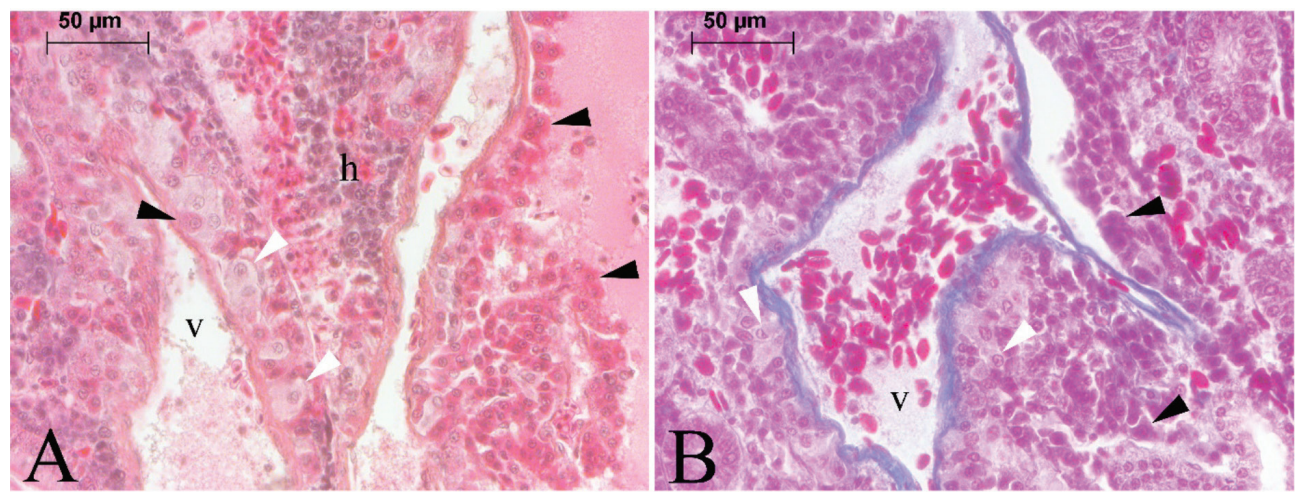

FIGURE 4. The interrenal gland in the longitudinal sections of the head kidney of pearl mullet. The interrenal cells are intermingled with chromaffin cells around the branches of the postcardinal vein and they displayed eosinophilic staining with H\&E (A) and acidophilic with MT (B) in their cytoplasms (black arrowheads). The chromaffin cells can be seen with their eosinophobic (A) or pale cytoplasm (B) among the interrenal cells (white arrowheads) (h: hematopoietic tissue; v: vein) 


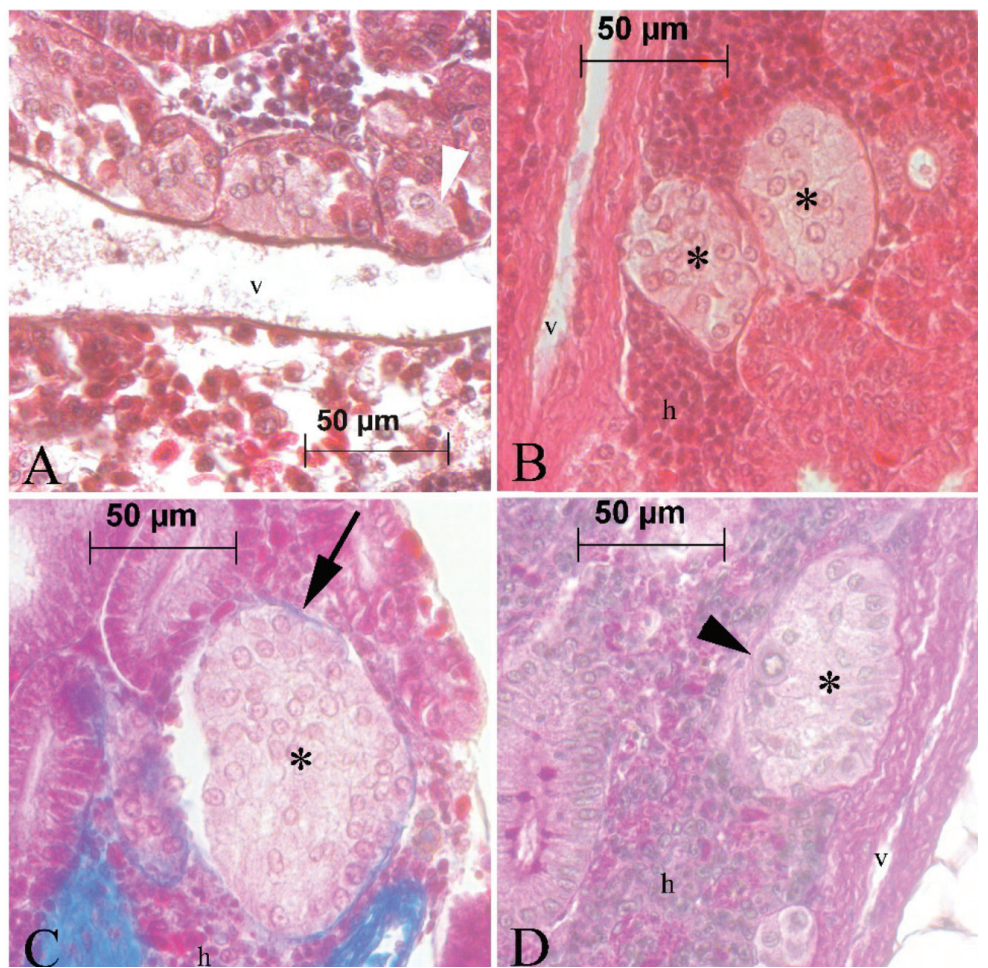

FIGURE 5. The chromaffin cells were observed to be intermingled with the interrenal cells at the branches of the postcardinal vein (A; white arrowhead) and they were also detectable in the walls of the main branches of the postcardinal groups $(*)$ (B, C , D) in the head kidney. The chromaffin cell groups were observed to be separated by a thin connective tissue (arrow) from the head kidney components, such as the hematopoietic tissue (h) (C). In some chromaffin cell groups, a presumable ganglion cell (black arrowhead) was determined (D). (A, B, H\&E; C, MT; D, PAS\&H; v: vein)

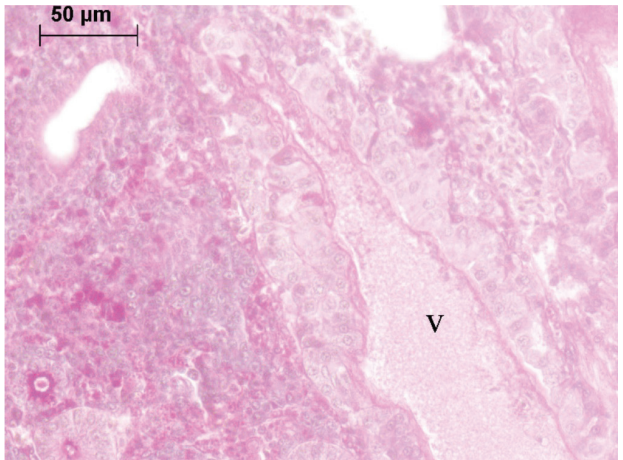

FIGURE 6. The interrenal and chromaffin cells showed a negative PAS staining (PAS\&H; v: vein)

follicles have been described in 13 of the 27 species belonging to Cyprinidae, such as common carp (Cyprinus carpio) and goldfish (Carrasius auratus) (Geven et al. 2007). The thyroid follicles in pearl mullet were found in the subpharyngeal region and were not observed in the head or trunk of the kidney. This is similar to zebrafish (Danio rerio), where all of the follicles in this fish were reported close to the ventral aorta, from the gill arch to the bulbus arteriosus (Wendl et al. 2002). The appearance of the epithelial cells of the thyroid follicles were observed to vary from cuboidal and cylindrical and in some occasions, follicles with squamose epithelial cells were determined among the examined fish. The epithelial cell height depends on TSH stimulation (Nishioka et al. 1987). In the unstimulated tissue, the follicles are usually large and their epithelial cells are squamose or cuboidal in appearance. Following thyrotropic stimulation of the thyroid tissue, the follicles tend to be smaller, the epithelial cells columnar. The appearance of the follicles can vary markedly between individuals of a given species, depending on the level of pituitary gland stimulation. Even within a gland, there is a marked variation in appearance, which suggests a variable response of the different follicles to thyrotropic stimulation (Leatherland 1994). The fish used in this study were sampled at a time near the reproductive season. It was reported that the height of the follicular epithelial cells of the thyroid tissue increased at the reproductive season in the white grouper (Epinephelus aeneus) and correlated with the reproductive status of the fish (Abbas et al. 2012). PAS staining resulted in a positive staining of the lumens of the thyroid follicles, which contains the colloidal suspension of an iodine-rich protein, called thyroglobulin. This finding is in agreement with other fish species, including Senegalese sole (Solea senegalensis) (Ortiz Delgado et al. 2006), short mackerel (Rastrelliger brachysoma) (Senarat et al. 2016), and zebrafish (Danio rerio) (Wendl et al. 2002).

The head kidney of pearl mullet is composed of hematopoietic tissues, melanomacrophage centers, the interrenal gland, chromaffin tissue, malpighian bodies and tubules of nephrons, as observed in most teleost fish 
(Morovvati et al. 2012). In the present study, the interrenal and chromaffin cells are located in the head kidney and are mainly associated with the postcardinal veins and its branches. Similar findings were also reported in other teleostean fishes (Chakrabarti 2014; Chakrabarti \& Ghosh 2014; Durkina 2006; Rocha et al. 2001; Sampour 2008). On the other hand, there are differences in the distribution and organization of these cells among fish species. In pearl mullet, both interrenal and chromaffin cells were observed to be intermingled around the small- and medium-sized branches of the post cardinal vein. In the intermingled areas of these cells, the interrenal cells were observed to form one to three cell layers. The chromaffin cells were also found to be situated in groups separated by a thin connective tissue in the walls of the main branches of the postcardinal vein. In rainbow trout (Oncorhyncus mykiss), the interrenal gland and chromaffin cells are distributed separately, not intermingled; whereas in common carp (Cyprinus carpio), the interrenal gland was seen as consisting of well-developed glandular masses around the postcardinal vein with branches penetrating the head kidney and the chromaffin cells are detectable among the interrenal cells (Aida et al. 1995). In matrinxã (Bryon cephalus), the interrenal cells present three pattern arrangements related to the blood vessels: two to three cell layers, well-defined groups and lobules and spreading inside with multiple cell layers around the sinusoids in the head kidney, while chromaffin cells are closely associated with postcardinal vein and its branches and form groups and they are separated from the interrenal cells by a thin layer of connective tissue (Rocha et al. 2001). In stickleback (Gasterosteus aculeatus), the gland tissue is composed of cords and nests of interrenal and chromaffin cells surrounding the post cardinal veins and their branches (Civinini et al. 2001). In cichlid fish (Cichlasoma dimerus), interrenal cells are found in contact with smaller veins and sinusoids of the postcardinal vein and arranged in groups or cords, separated from each other and from the parenchyma of hematopoietic cells by a thin layer of connective tissue, while the chromaffin cells are situated in groups just below the main veins (Morandini et al. 2014). Thus, it can be said that the distribution of the interrenal and chromaffin cells in pearl mullet displays similarities to other fish species with some differences.

In this study, the cytoplasm of the interrenal cells was determined to be deeply eosinophilic. The nuclei of the interrenal cells were usually round and basophilic. The histochemical observations were similar to those of other fish species, where the eosinophilic coloration of the cytoplasm of interrenal cells was also reported in matrinxã (Bryon cephalus) (Rocha et al. 2001), pacu (Piaractus mesopotamicus) (Gazola et al. 1995), flounder (Durkina 2006) and cichlid fish (Cichlasoma dimerus) (Morandini et al. 2014). The chromaffin cells were larger than the interrenal cells, when stained with $\mathrm{H} \& \mathrm{E}$ they exhibited a pale cytoplasm and had a large slightly basophilic nucleus with a prominent nucleolus. Those results coincide with most teleost fishes (Chakrabarti 2014; Chakrabarti \& Ghosh 2014; Durkina 2006; Rocha et al. 2001; Sampour 2008). In some instances, the chromaffin cell groups were observed to be associated with a ganglion cell in pearl mullet. Genten et al. (2008) and Morandini et al. (2014) also observed a ganglion cell in the chromaffin tissue of Scyliorhinus canicula and cichlid fish (Cichlasoma dimerus) species, respectively. Histochemically, both the interrenal and chromaffin cells of pearl mullet displayed a negative reaction to PAS staining. Such an observation demonstrates that the amounts of glycoprotein, glycolipid, glycogen and mucopolysaccharide contents of these cells are very small. The negative staining of those cells with PAS was also reported in the other teleost fish such as Anabas scandens (Misra 1991), fathead minnow (Pimephales promelas) (Yoakim \& Grizzle 1980) and matrinxã (Bryon cephalus) (Rocha et al. 2001).

\section{CONCLUSION}

In conclusion, the thyroid tissue of pearl mullet was found to be unencapsulated and scattered diffusely under the pharyngeal region, located in the dorsal and lateral aspects of the ventral aorta. On the other hand, the interrenal and chromaffin tissues were located along the postcardinal vein and its branches in the head kidney. These cells were found to be intermingled around the small- and medium-sized branches; however, the chromaffin cells were also observed to be situated separately in groups in the walls of the main veins. There have been no reports on the histological organization of the thyroid and interrenal gland in pearl mullet until now. Thus, the findings from this work will provide basic information for endocrinological studies in the future for this species.

\section{ACKNOWLEDGEMENTS}

The author(s) received no financial support for the research and/or authorship of this article.

\section{REFERENCES}

Abbas, H.H., Authman, M.M., Zaki, M.S. \& Mohamed, G.F. 2012. Effect of seasonal temperature changes on thyroid structure and hormones secretion of white grouper (Epinephelus aeneus) in Suez Gulf, Egypt. Life Science Journal 9: 700-705.

Abdel-Aziz El-S. H., El-Sayed Ali, T., Abdu, S.B.S. \& Fouad, H.F. 2010. Chromaffin cells and interregnal tissue in the head kidney of the grouper, Epinephilus tauvina (Teleostei, Serranidae): A morphological (optical and ultrastructural) study. Journal of Applied Ichthyology 26: 522-527.

Aida, K., Kaneko, T., Oguri, M. \& Sato, H. 1995. Endocrine system. In An Atlas of Fish Histology, 2nd. ed., edited by Takashima, F. \& Hibiya, T. Tokyo-Stuttgart New York: Kodansha-Gustav Fischer Verlag. pp. 154-185.

Chakrabarti, P. \& Ghosh, S.K. 2014. Cyclical changes in interrenal and chromaffin cells in relation to testicular activity of olive barb, Puntius sarana (Hamilton). Archives of Polish Fisheries 22: 151-158. 
Chakrabarti, P. 2014. Histological features of interrenal and chromaffin cells in relation to seasonal testicular activities in Notopterus notopterus (Pallas, 1769). Iranian Journal of Ichthyology 1: 206-213.

Civinini, A., Padula, D. \& Gallo, V.P. 2001. Ultrastructure and histochemical study on the interrenal cells of the male stickleback (Gasterosteus aculeatus, Teleostea), in relation to the reproductive annual cycle. Journal of Anatomy 199: 303-316.

Danulat, E. \& Selcuk, B. 1992. Life history and environmental conditions of the anadromous Chalcalburnus tarichi (Cyprinidae) in the highly alkaline lake Van, Eastern Anatolia, Turkey. Archiv fur Hydrobiologie 126: 105-125.

Durkina, V.B. 2006. The state of the interrenal gland in plaices Pleuronectes pinnifasciatus and P. obscurus from two stations in Amurskii Bay (Sea of Japan). Journal of Ichthyology 46: 195-199.

Eales, J.G. \& Brown, S.B. 1993. Measurement and regulation of thyroidal status in teleost fish. Reviews in Fish Biology and Fisheries 4: 299-347.

Gallo, V.P. \& Civinini, A. 2003. Survey of the adrenal homolog in teleosts. International Review of Cytology 230: 89-187.

Gazola, R., Borella, M.I., Val-Sella, M.V., de Moraes F.F. \& Bernardino, G. 1995. Histophysiological aspects of the interrenal gland of the pacu female, Piaractus mesopotamicus (Teleostei, Cypriniformes). Boletim Técnico do CEPTA, Pirassununga 8: 1-12.

Genten, F., Terwinghe, E. \& Danguy, A. 2008. Endocrine Glands. In Atlas of Fish Histology (Chapter 13). Enfield, NH, USA: Science Publishers. p. 223.

Geven, E.J.W., Nguyen, N.K., van den Boogaart, M., Spanings, F.A.T., Flik, G. \& Klaren, P.H.M. 2007. Comparative thyroidology: Thyroid gland location and iodothyronine dynamics in Mozambique tilapia (Oreochromis mossambicus Peters) and common carp (Cyprinus carpio L.). Journal of Experimental Biology 210: 4005-4015.

Janz, D.M. 2000. Endocrine system. In The Laboratory Fish, edited by Ostrander, G.K. San Diego: Academic Press. pp. 189-217.

Kaptaner, B. \& Kankaya, E. 2013. Analysis of germ cell proliferation, apoptosis, and androgenesis in the Lake Van fish (Chalcalburnus tarichi) during testicular development. Fish Physiology and Biochemistry 39: 1165-1679.

Leatherland, J.F. 1994. Reflections on the thyroidology of fishes: From molecules to humankind. Guelph Ichthyology Reviews 2: 1-64.

Misra, S.K. 1991. Histo-enzymological analysis on the interrenal tissue of the teleost, Anabas scandens (Bloch). Indian Biol. 23: $28-30$.

Morandini, L., Honji, R.M., Ramallo, M.R., Moreira, R.G. \& Pandolfi, M. 2014. The interrenal gland in males of the cichlid fish Cichlasoma dimerus: Relationship with stress and the establishment of social hierarchies. General and Comparative Endocrinology 195: 88-98.

Morovvati, H., Mahabady, M.K. \& Shahbazi, S. 2012. Histomorphological and anatomical study of kidney in berzem (Barbus pectoralis). International Journal of Fisheries and Aquaculture 4: 221-227.
Nishioka, R.S., Grau, E.G., Lai, K.V. \& Bern, H.A. 1987. Effect of thyroid-stimulating hormone on the physiology and morphology of the thyroid gland in coho salmon, Oncorhynchus kisutch. Fish Physiology and Biochemistry 3: 63-71.

Ortiz Delgado, J.B., Ruane, N.M., Pousão-Ferreira, P., Dinis, M.T. \& Sarasquete, C. 2006. Thyroid gland development in Senegalese sole (Solea senegalensis Kaup 1858) during early life stages: A histochemical and immunohistochemical approach. Aquaculture 260: 346-356.

Raine, J.C. 2011. Thyroid hormones and reproduction. In Hormones and Reproduction of Vertebrates. Volume 1Fishes, Chap. 25, edited by Norris, D.O. \& Lopez, K.H. Elsevier: Academic Press.

Raine, J.C., Takemura, A. \& Leatherland, J.F. 2001. Assessment of thyroid function in adult medaka (Oryzias latipes) and juvenile rainbow trout (Oncorhynchus mykiss) using immunostaining methods. Journal of Experimental Zoology 290: 366-378.

Raine, J.C. \& Leatherland, J.F. 2000. Morphological and functional development of the thyroid tissue in rainbow trout (Oncorhynchus mykiss) embryos. Cell and Tissue Research 301: 235-244.

Rocha, R.M., Leme-Dos Santos, H.S., Vicentini, C.A. \& Da Cruz, C. 2001. Structural and ultrastructural characteristics of interrenal gland and chromaffin cell of Matrinxã, Brycon cephalus Gunther 1869 (Teleostei-Characidae). Anatomia Histolologia Embryologia 30: 351-355.

Sampour, M. 2008. The study of adrenal chromaffin of fish, Carassius auratus (Teleostei). Pakistan Journal of Biological Sciences 11: 1032-1036.

Senarat, S., Kettratad, J., Lampang, P.N., Gettongsong, T., Karnjanapak, C., Palasai, A., Kangwanrangsan, N. \& Jiraungkoorskul, W. 2016. Structural organization of the thyroid gland and interrenal tissue with reference to endocrine parenchyma in short mackerel, Rastrelliger brachysoma (Bleeker, 1851). Agriculture and Natural Resources 50: 60-63.

Wendl, T., Lun, K., Mione, M., Favor, J., Brand, M., Wilson, S.W. \& Rohr, K.B.2002.Pax2.1 is required for the development of thyroid follicles in zebrafish. Development 129: 3751-3760.

Yoakim, E.G. \& Grizzle, J.M. 1980. Histological, histochemical and ultrastructural studies on the interrenal and chromaffin cells of the fathead minnow, Pimephales promelas Rafinesque. J. Fish Biol. 17: 477-494.

Department of Biology

Faculty of Science

Van Yüzüncü Y1l University

65080 Tuşba, Van

Turkey

*Corresponding author; email: bkaptaner@yahoo.com

Received: 6 June 2016

Accepted: 6 January 2017 